\title{
Assessment of Factors that Influence Participants Level of Participation in Fadama III Agricultural Project in Bayelsa State, Nigeria
}

\author{
Ominikari, Abraham G..$^{1 *}$, Onumadu, Francis N. ${ }^{2}$, Gideon Nnamerenwa ${ }^{3}$
}

\author{
${ }^{1}$ Department of Agricultural Economics and Extension, Federal Polytechnic Ekowe, Bayelsa State, Nigeria \\ ${ }^{2}$ Department of Rural Sociology and Extension, Michael Okpara University of Agriculture, Umudike, Abia State, Nigeria \\ ${ }^{3}$ Department of Agricultural Economics, Michael Okpara University of Agriculture, Umudike, Abia State, Nigeria
}

\begin{abstract}
The study assessed factors that influenced participant's level of participation of fadama III agricultural project in bayelsa state. Objectives were the participant's socioeconomic characteristics, and the factors that influenced participant's level of participation. Purposive sampling technique was used to select 150 farmers that participated, and 150 staff from the delivery agency. Data were collected with a structured questionnaire. Objective one was analyzed using descriptive statistics, while inferential statistics such as ordinary least square (OLS) regression analysis was used. The finding showed that farmers were averagely 42.6 years old, $54.7 \%$ of the farmers were females while $45.4 \%$ were males, $72.1 \%$ of the farmers were married. The farmers farm averagely 0.9 hectares and had averagely 7 persons per household. The farmers were literate, experienced in farming with mean monthly estimated income from Fadama of $\$ 44,133.83$. Extension visit to farmers was low with 38.7 percent being the largest proportion of the entire sampled farmers. Age of respondents, food security status, household size, and income level, and poverty status, leadership propensity, farming experience, educational level and distance to Fadama III training centre influenced participant's level of participation in Fadama III agricultural project in Bayelsa state. The study concludes that agricultural and rural development projects such as fadama III are fundamental to nation building and the agricultural sector is what can fast track the challenges faced by rural dwellers in terms of agricultural development in most of the developing countries. The study recommends that funds meant for agricultural projects be properly disbursed to farmers to enable them participate actively as farmer's income level motivate them to participate in agricultural and rural development projects.
\end{abstract}

Keywords - Agricultural, Bayelsa State, Fadama III, Influence, Participation.

\section{INTRODUCTION}

The National Fadama Development Project was introduced as a strategy to tackle rural development problems. There are quite a number of studies on rural development in general and fadama project in particular. These studies have been carried out in different parts of Nigeria and on different aspect of the impact analysis of the National Fadama Development Project.

Fadama areas are typically waterlogged in the rainy season but retain moisture during the dry seasons. Fadama areas are considered to be of high potential for economic development through appropriate investments in productive assets, rural infrastructure and technical assistance. The desire to harness the verse potentials of Fadama in Nigeria culminated in the design of National Fadama Development Project I, II and III. Fadama I (Phase I of the National Fadama Development Project) was implemented during the 1993-1999 period. While, Fadama I focused mainly on crop production, downstream activities such as processing, preservation and marketing were largely neglected. The design did not take into cognizance of need for spatial integration of the markets (creating of physical and market infrastructure). It also failed to take into consideration other Fadama resource users such as livestock producers, fishing folks, pastoralists, hunters etc. The project did not also support post-harvest technology, which manifested in reduced crop prices and increased storage losses during the period, [1].

Some of the lessons learnt in Fadama I informed the birth of Fadama II. Fadama II was targeted at dry season farming agro-processing, preservation and marketing. It also allowed for acquisition of productive assets, provision of 
rural infrastructure to ensure the efficient transportation of farm output to markets as well as marketing activities. The project development objective was to sustainably increase the incomes of the beneficiaries through empowering communities to take charge of their own development agenda through Community Drive Development (CDD) approach in project implementation in a socially inclusive manner. Fadama II also provides special preferences to groups of youths, women (especially widows), physically challenged, the elderly and people with HIV/AIDs, [2].

Fadama III project is a follow-up to the Fadama II project which was assessed to have impacted the lives of rural farmers, raising their incomes by 63 percent. The project like Fadama II takes the CDD approach, which places beneficiaries in driver's seat. Local community members under the umbrella of Fadama Community Associations (FCAs and Fadama Users Groups (FUGs), oversee the design and implementation of the project and are empowered through skills and capacity building to improve their livelihoods by increasing income generating activities.

\section{THE SPECIFIC OBJECTIVES WERE:}

i) describe the socio-economic characteristics of the participants in the study area,

ii) determine the factors that influence the level of participation of the respondents in Fadama III agricultural project in the study area.

\section{METHODOLOGY}

The study was carried-out in Bayelsa State; the State is made up of eight Local Government Areas, namely: Brass, Ekeremor, Kolokuma/Opokuma, Nembe, Ogbia, Sagbama, Southern Ijaw and Yenagoa Local Government Areas respectively. Each of this L.G.As is known as Agricultural districts. The major occupation of the people is farming and fishing, [3]. Purposive sampling technique was used to select the communities that participated in Fadama III Project; one (1) Local Government Area was used to represent each of the three (3) Agricultural zones, five Fadama communities were used to represent each of the selected Local Government Areas, the Local Government Areas were Kolokuma/Opokuma, Ogbia and Sagbama respectively, ten (10) participants belonging to a Fadama User Group were selected from each of the communities which gave us a sample size of One-Hundred and fifty (150) respondents.

3.1 Method of Data Analysis

Data collected from the survey were analyzed using descriptive statistics such as frequency, percentages and mean for objective one (1) while Objective two (2) was analyzed using ordinary least square multiple regression analysis technique.

3.2 Model Specification for Ordinary Least Square

Regression Analysis

The ordinary least square regression model used to estimate the factors that influenced the level of participation of farmers in Fadama III Agricultural project in Bayelsa state is given in implicit form as:

PFFAP $=f\left(\mathrm{X}_{1}, \mathrm{X}_{2}, \mathrm{X}_{3}, \mathrm{X}_{4}, \mathrm{X}_{5}, \mathrm{X}_{6}, \mathrm{X}_{7}, \mathrm{X}_{8}, \mathrm{X}_{9}, \mathrm{X}_{10}, \mathrm{X}_{11}, \mathrm{X}_{12}\right.$, $\left.\mathrm{X}_{13}, \mathrm{e}\right)$.....

Where,

PFFAP $=$ Participation in Fadama III agricultural project (mean response of the respondent on a 4 point likert type rating);

$\mathrm{X}_{1}=$ Age of respondents (years);

$\mathrm{X}_{2}=$ Gender (Dummy variable: $1=$ male; $0=$ female $)$; $\mathrm{X}_{3}=$ Food security $\left.\frac{\text { Per capita Food expenditure for the } \mathrm{i}^{\text {th }} \text { household }}{2 / 3 \text { mean per capita food expenditure of all households }}\right)$;

When Fi $\geq 1=$ food secure $i^{\text {th }}$ household and when Fi $\leq 1=$ food insecure $i^{\text {th }}$ household.

$\mathrm{X}_{4}=$ Household size (Counts of people living in the same home and feeding from the same pot);

$\mathrm{X}_{5}=$ Income level (Naira);

$\mathrm{X}_{6}=$ Poverty status of the respondents (Measured as Mean per Capita Household Expenditure (MCHE));

$\mathrm{X}_{7}=$ Marital status (Married $=1$; Unmarried $=0$ );

$\mathrm{X}_{8}=$ Farm size (Hectares)

$\mathrm{X}_{9}=$ Leadership style (Supportive $=1$; Unsupportive $=0$ )

$\mathrm{X}_{10}=$ Farming experience (years)

$\mathrm{X}_{11}=$ Educational level (years spent in schooling)

$\mathrm{X}_{12}=$ Distance to Fadama III training centre (kilometers);

$\mathrm{X}_{13}=$ Cooperative membership $(\mathrm{Yes}=1 ; \mathrm{No}=0)$

$\mathrm{e}=$ error term.

The logit regression analysis used to estimate the significant factors that influenced the effectiveness of Fadama III project in empowering the participants in the study area is given in implicit form as:

$\mathrm{EFAEP}=f\left(\mathrm{Z}_{1}, \mathrm{Z}_{2}, \mathrm{Z}_{3}, \mathrm{Z}_{4}, \mathrm{Z}_{5}, \mathrm{Z}_{6}, \mathrm{Z}_{7}, \mathrm{Z}_{8}, \mathrm{Z}_{9}, \mathrm{Z}_{10}, \mathrm{Z}_{11}, \ldots \ldots\right.$, $\left.\mathrm{Z}_{21}, \mathrm{Z}_{22}, \mathrm{Z}_{23}, \mathrm{e}\right)$.

Where,

EFAEP = Latent dummy variable indexing effectiveness of Fadama III project in empowering the participants (Effective $=1$; Not effective $=0$ );

$\mathrm{Z}_{1}=$ Delay in provision of advisory services $(\mathrm{Yes}=1$; No $=$ $0)$

$Z_{2}=$ Unavailability of funds for loan services $($ Yes $=1 ;$ No $=$ 0) 
$\mathrm{Z}_{3}=$ Quality of technical advice $($ Good $=1 ;$ Poor $=0)$

$\mathrm{Z}_{4}=$ Relationship with project communities $($ Cordial $=1$; Hostile $=0$ )

$\mathrm{Z}_{5}=$ Types of enterprise farmers participate in (Crop production $=1$; livestock production $=2$; Apiculture $=3$; Fish production $=4$; Snail production $=5$ )

$\mathrm{Z}_{6}=$ Attitude to work of the Fadama delivery personnel $($ Good $=1$; Poor $=0)$

$\mathrm{Z}_{7}=$ Resourcefulness of the Fadama delivery personnel (Resourceful $=1$; Non- resourceful $=0$ )

$\mathrm{Z}_{8}=$ Leadership style of the Fadama delivery personnel (Supportive $=1$; Unsupportive $=0$ )

$Z_{9}=$ Number of Fadama delivery personnel (Abundant manpower=1; Few manpower $=0$ )

$\mathrm{Z}_{10}=$ Inadequate funding $(\mathrm{Yes}=1 ; \mathrm{No}=0)$

$\mathrm{Z}_{11}=$ Redundancy of Fadama delivery personnel (Yes =1;

No $=0$ )

$\mathrm{Z}_{12}=$ Delay in input delivery $($ Yes $=1 ; \mathrm{No}=0)$

$\mathrm{Z}_{13}=$ Educational competency of delivery personnel $($ Competent $=1 ;$ Not competent $=0)$

$\mathrm{Z}_{14}=$ Distrust of delivery agent personnel by farmers (Yes $=1$; No $=0$ )

$\mathrm{Z}_{15}=$ Unnecessary bureaucracy $(\mathrm{Yes}=1 ; \mathrm{No}=0)$

$\mathrm{Z}_{16}=$ Inadequate availability of operational logistics (Yes

$=1 ;$ No $=0$ )

$\mathrm{Z}_{17}=$ Supply of unviable/insufficient farm inputs (Yes $=1$;

No $=0$ )

$\mathrm{Z}_{18}=$ Poor monitoring of project activities $(\mathrm{Yes}=1 ; \mathrm{No}=0)$

$\mathrm{Z}_{19}=$ High cost of management of project activities (Yes $=1 ;$ No $=0$ )
$\mathrm{Z}_{20}=$ Farmers unwillingness to participate (Yes $=1 ; \mathrm{No}=0$ ) $\mathrm{Z}_{21}=$ Limited Information on improved technologies $($ Unlimited $=1 ;$ Limited $=0)$

$\mathrm{Z}_{22}=$ Climatic uncertainties/flooding (Yes $=1 ; \mathrm{No}=0$ )

$\mathrm{Z}_{23}=$ Low adoption of technology $($ Yes $=1 ; \mathrm{No}=0)$

$\mathrm{e}=$ error term.

\section{RESULTS AND DISCUSSION}

4.1 Fadama III Agricultural Project Participants Socioeconomic Characteristics in Bayelsa State

4.1.1 Age of respondents

The distribution of the respondents by their age shows that majority (41.3\%) of the farmers who participated in Fadama III Agricultural project in Bayelsa State were within the age bracket of 41-50 years old while the least $(8.7 \%)$ of the farmers who participated in Fadama III Agricultural project in Bayelsa State were within the age bracket of 21-30 years old. The mean age of the respondents was 42.6years old. This implies that most of the farmers that participated in Fadama III Agricultural project in Bayelsa State were still in their active stage in life and can be effective in utilizing any training they received from Fadama III Agricultural project in Bayelsa State to better their income generating capacity and better their standard of living. [4] And [5] succinctly observed that farmers within the active age brackets have more innovative ability and capacity to do manual work than farmers in their inactive age. The pie chart representation of the percentage variations in the ages of the sampled farmers in Fadama III Agricultural projects in Bayelsa state is presented in figure 1 below.

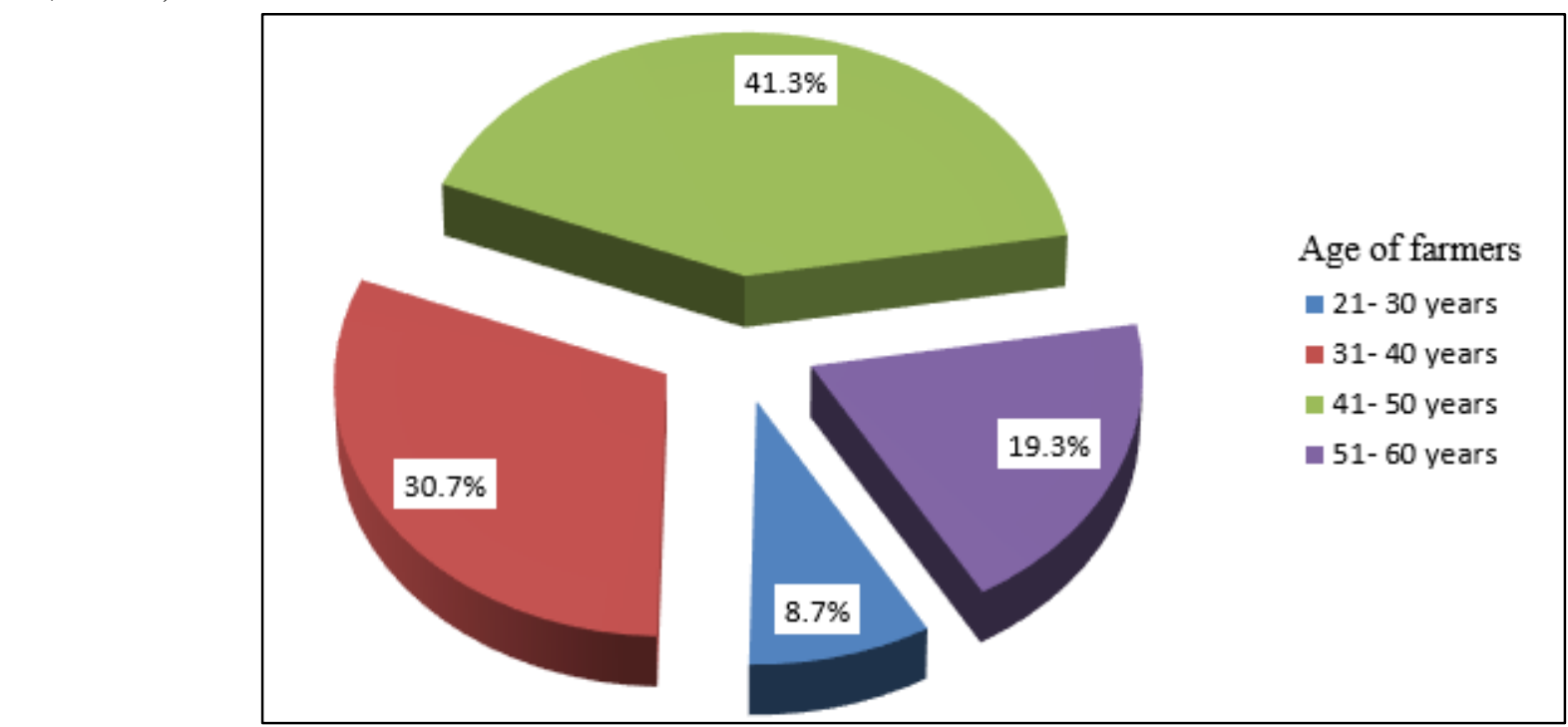

Fig. 1: pie chart representation of the percentage variations in the ages of the sampled farmers participating in fadama iii agricultural projects in bayelsa state. 
4.1.2 Gender of respondents

The distribution of respondents by gender shows that, 82 farmers representing $54.7 \%$ of the entire sampled farmers were females while 68 farmers representing $45.4 \%$ of the entire sampled farmers were males. This indicates that female were more involved in Fadama III Agriculture project activities in the area studied than their male counterparts. This finding is consistent with [6], [7] and [8] who noted that female farmers often engaged in Agricultural activities than male farmers in their various studies with a relevant observation that men especially the youths that are suppose to embrace farming are neglecting Agriculture and probably migrating from the rural villages to the cites in search of white collar jobs, while the women still remain and engaged in agriculture despite their dual roles as farmers and mothers. This assertion was further confirmed by [9] who reported that women constitute the major actors in all aspects of life. [10] in their study noted that the role women play and their position in meeting the challenges of Agricultural production and Development are quite dominant and prominent. Their relevance and significance in Agriculture, therefore, cannot be overemphasized [11]; [12]. Findings from a study financed by the United Nations Development Programme (UNDP) revealed that women make up some 60 to $80 \%$ of Agricultural labour force in Nigeria [13], depending on the region and they produce two-third of the food crops. Yet, in spite of these, widespread assumption that men - and not women - make the key farm management decisions has prevailed. Sadly, female farmers in the country are among the voiceless, especially with respect to influencing Agricultural policies. The bar chart representation of the percentage variations in the gender of the sampled farmers in Fadama III Agricultural projects in Bayelsa state is presented in figure 2 below.

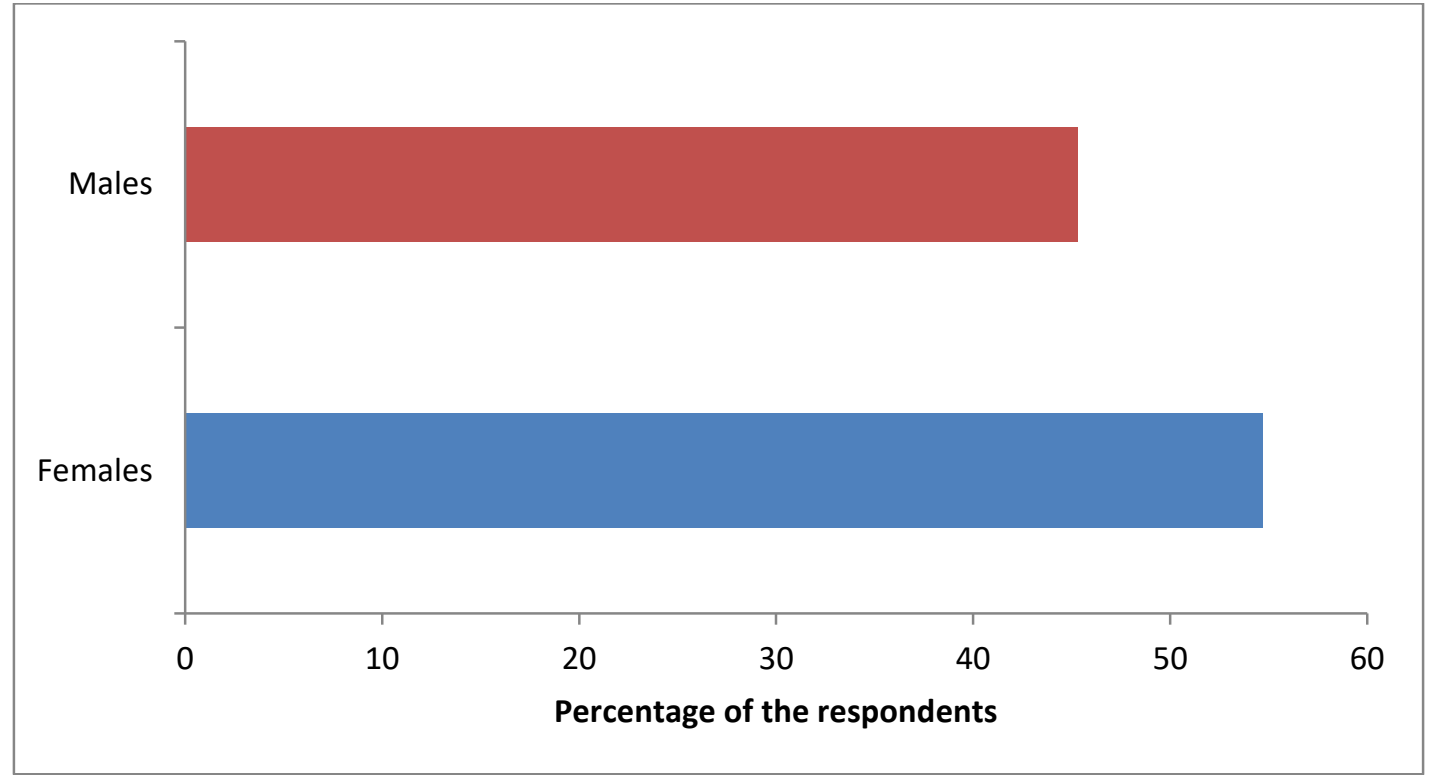

Fig.2: bar chart representation of the percentage variations in the gender of the sampled farmers participating in fadama iii agricultural project in bayelsa state.

\subsubsection{Marital Status}

For marital status, larger proportion $(72.1 \%)$ of the respondens was married while 9.3 percent were single, 3.3 percent were divorced. 11.3 percent were widows and 4.0 percent were widowers. This implies that married individuals dominated among the sampled farmers that participated in Fadama III Agricultural project. The plethora of married people has huge implication for family labour supply, [14]. Marriage predisposes an Individual to become more responsible than even being since they must cater for their family needs. The high percentage of the married individuals in Agriculture is consistent with [15] who reported that getting married is highly cherished among farming families in rural areas of Nigeria due to their relevance in boosting family labour supply. The bar chart representation of the percentage variations in the marital status of the sampled farmers in Fadama III Agricultural projects in Bayelsa state is presented in figure 3 below. 


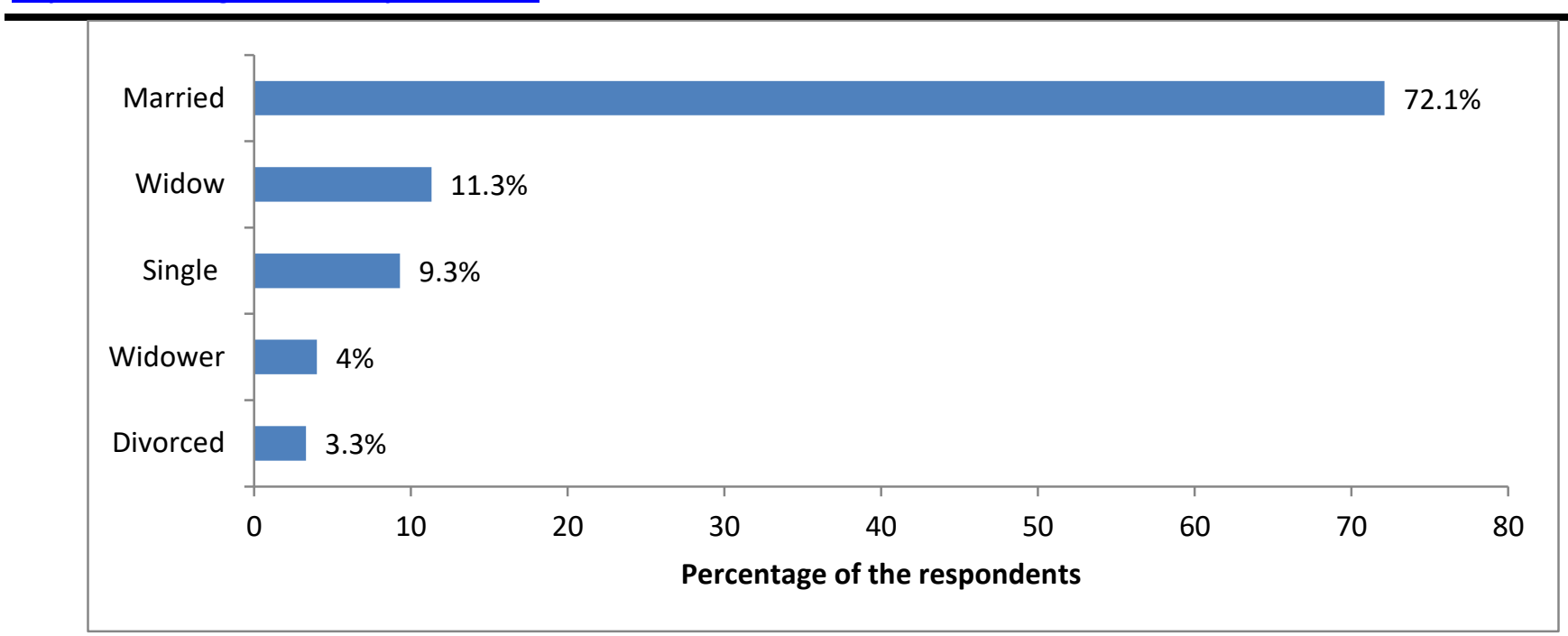

Fig. 3: bar chart representation of the percentage variations in the marital status of the sampled farmers in fadama iii agricultural projects in bayelsa state

\subsubsection{Farm size}

The result with respect to farm size showed a larger proportion of the respondents 78.7 percent had farmed sizes of at most one (1) hectare. This was followed by 10.7 percent of the respondents with farm sizes of at most two (2) hectares. The least proportion of the respondents 0.7 percent had farm sizes of at most five (5) hectares. The mean farm size of the respondents in the study area was 0.9 hectares. This implies that most of the farmers that participated in Fadama III Agricultural project in Bayelsa state were small scale farmers who are subsistent in nature. [16] noted that farmers that have small farm size produce for their family consumption. The implication of the finding shows that rural farmers had only little land to cultivate their arable crops because of the geographical location of their domain and this means that access to land is limited in the study area. This may be due to the scarcity of land and constant fragmentation of available land in the study area which was necessitated by constant oil spillage in most parts of the state. According to [17], the small farm sizes cultivated by farmers may be due to land fragmentation most common in rural areas and such smaller farm size would lead to smaller output and smaller income for the owner of such farms. The series of fragmentation of farm lands in the rural area is because most land is gotten from heritage [18]. This finding is consistent with [19] who succinctly observed that the size of farm cultivated is a function of population pressure, family size and financial capacity of the farmers; and with [20] who averred that the quantity of crops planted by a farm firm depends on the quantity of land available to it. The study is also consistent with [21], who asserted that limited access to land limits the size and scale of the farm business. The column chart representation of the percentage variations of farm sizes (hectares) of the sampled farmers in Fadama III Agricultural projects in Bayelsa state is presented in figure 4 below. 


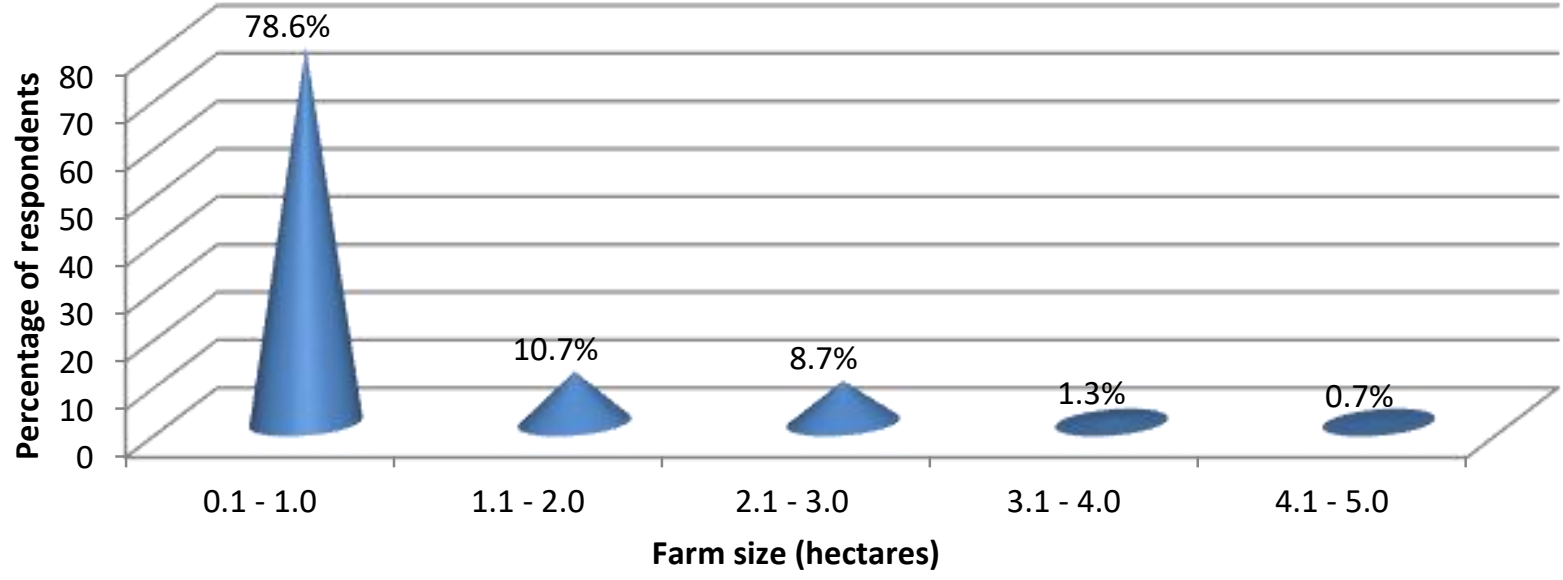

Fig. 4: column chart representation of the percentage variations of farm size of the sampled farmers in fadama iii agricultural projects in bayelsa state.

\subsubsection{Household size}

[22] Define household size as the number of people eating from one pot. It implies that the consumption unit is also the production unit. Family composition is an important variable in Agricultural production [23]. The finding shows that larger proportion (50.7 percent) of the farmers that participated in Fadama III Agricultural project in Bayelsa state had a household size of between 6 and 10 persons per household while a fewer proportion (17.3 percent) of them had a household size of at most 15 persons per household. The mean household size of the respondents was 7 persons per household. This implies that the farmers that participated in Fadama III Agricultural project in Bayelsa state had relatively large household size. This large household size may have positive implications for these rural farming households since it has been found that most rural households depend on their family members to provide labour on the farm [24] and [25]. The study is also in line with [26] who reported that farmers are committed in whatever they do because they have a large household size that depends on them for food, shelter and clothing. The larger the size of a household the more it could provide farm labour and the lower will be their expenses on hired labour. However, large household sizes have been noted to have correlation with food insecurity and poverty especially when the household head is engaged in Agriculture as the main source of livelihood and income, [27]. [28] Also assert that household size has a significant impact on aggregate food expenditure especially when there are more young children in the household who do not contribute to household income generation. The column chart representation of the percentage variations in the household size of the sampled farmers in Fadama III Agricultural projects in Bayelsa state is presented in figure 5 below. 


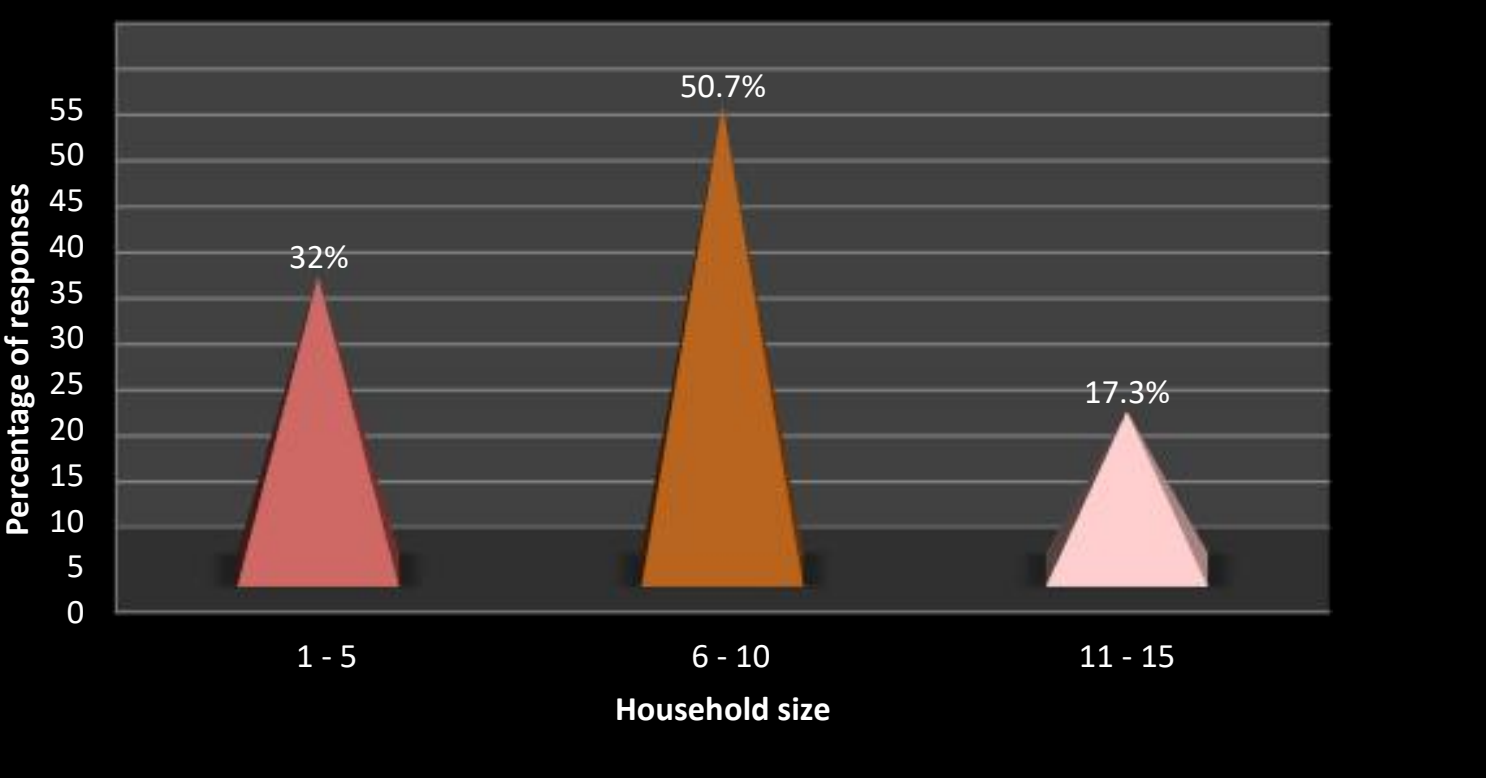

Fig. 5: column chart representation of the percentage variations in the household size of the sampled farmers in fadama iii agricultural project in bayelsa state.

\subsubsection{Mode of farming involvement}

The result for mode of farming involvement showed that larger proportion of the respondents (62.7 percent) of the sampled farmers for the study were into farming on a fulltime basis while fewer proportion of the respondents (37.3\%) were part-time farmers. This implies that most of the participants in Fadama III Agricultural projects in the study area are devoted farmers who take farming as their major business and means of generating income of their well being and survival. This is consistent with the findings of [14] who succinctly observed that full time farmers are more adoptive to new farming systems and new or improved innovations than part-time farmers since the former depend so much on the outcome of their farming activities for their survival. The pie chart representation of the percentage variations in the mode of farming involvement of the sampled farmers in Fadama III Agricultural projects in Bayelsa state is presented in figure 6 below.
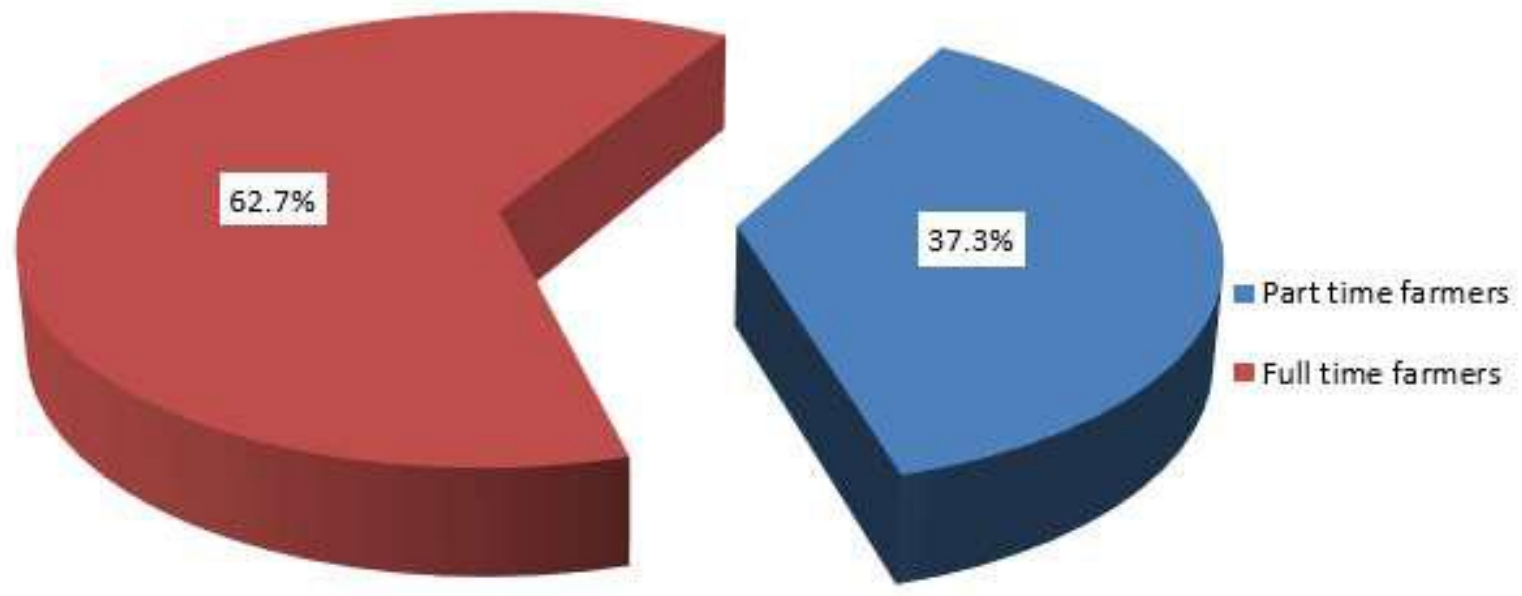

Fig. 6: Percentage variations in the mode of farming involvement of the sampled farmers in fadama III agricultural project in Bayelsa state 
1.7 Monthly estimated income from fadama ( $)$

The distribution of the respondents by monthly estimated income from Fadama shown in the result revealed that larger proportions (57.3 percent) of the sampled farmers for the study earned at least $\$ 50,000$ per month from their farming activities while fewer proportions (4.7 percent) of them earned at most $\$ 10,000$ per month from their farming activities. The mean monthly estimated income from Fadama of the sampled farmers in the study area was $\$ 44$, 133.83. This implies that the monthly income of the farmers in the study area is quite low and points to the fact that Fadama project in Bayelsa State may not have improved on the financial status of its participants so much as expected. [29] and [30] have noted that Fadama farming has led to increased productivity and output, and thus increased income among the participating farmers. The increased income provides more funds for capital investment especially since personal fund is a major source of credit for the respondents. It should also translate into better standard of living for this group of farmers because as noted by [31], there is an assumption by economists that a person with higher income is deemed to enjoy a higher living standard. This result agrees with the findings of [32] who reported higher farm incomes for Fadama beneficiaries than the non beneficiaries in their study areas. The assertion is in line with the studies of [33] and [34], whose study were conducted in Ogun and Gombe States respectively, and showed that Fadama project had no significant impact on participant's income, assets and/or poverty status. According to [35], income from farming activities is very low and there is general poverty amongst small holder farmers in Bayelsa state. The pie chart representation of the percentage variations in the monthly estimated income from Fadama of the sampled farmers in Fadama III Agricultural projects in Bayelsa state is presented in figure 7 below.

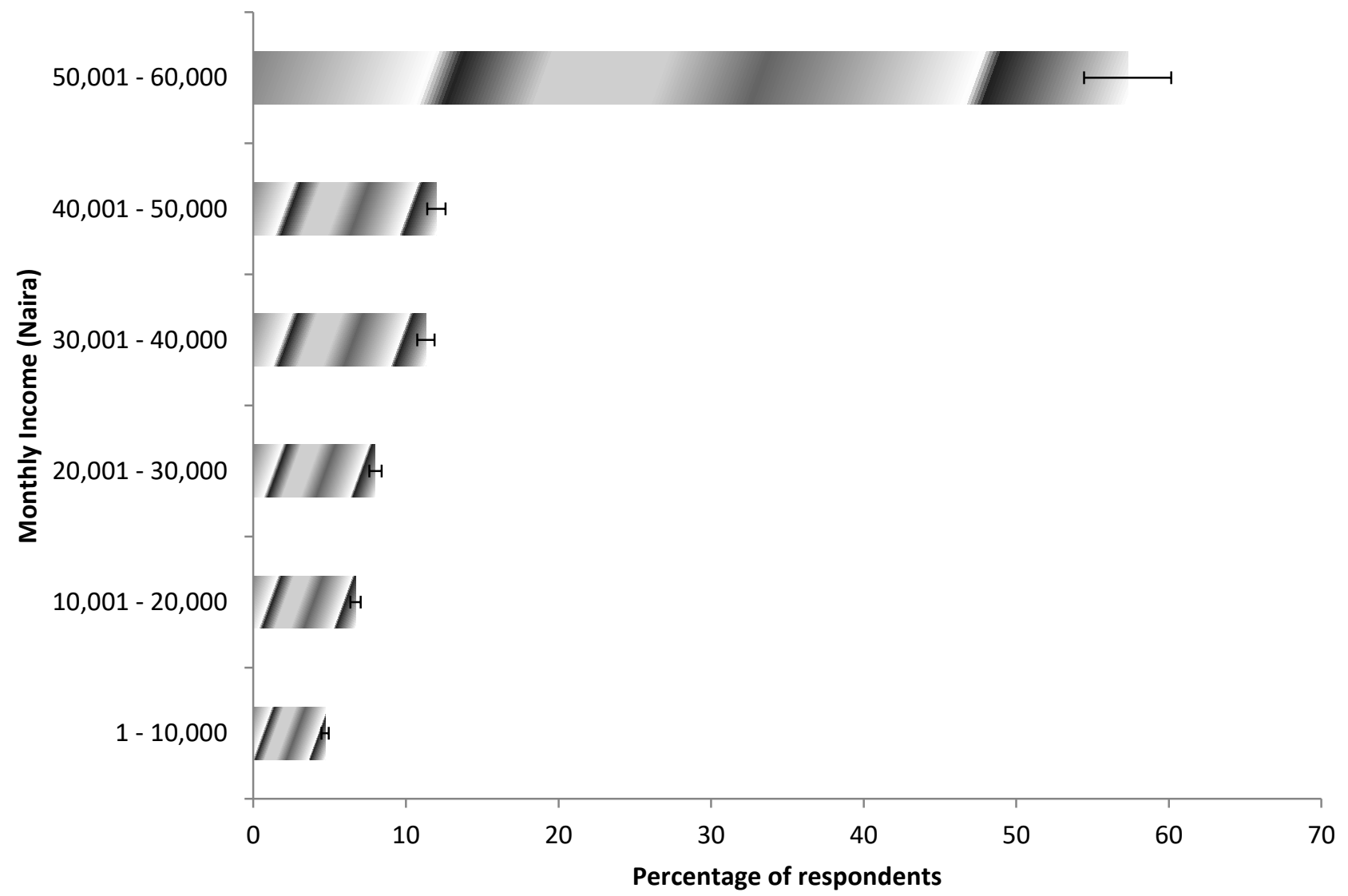

Fig.7: percentage variations in the monthly estimated income from fadama of the sampled farmers in fadama iii agricultural project in bayelsa state. 
4.1.8 Educational qualification

The distribution of respondents by educational status shows that larger proportions (67.3 percent) of the sampled respondents for the study had tertiary education while fewer proportions (2.7 percent) of them had no formal education. In all, 97.3 percent of the respondents had one form of formal education or another. This implies that most of the farmers that participated in Fadama III Agricultural projects were literate. The implication of this is that these households are better positioned to take advantage of new techniques and technologies that could lead to increased Agricultural output. This is imperative as it will enable the farmers to be able to understand and communicate basic principles guiding each of the activities made available to farmers through Fadama III Agricultural project and will also affect their performance. The finding was consistent with [36] and [37], noted that education will likely enhance the adoption of modern adaptation strategies, thereby sustaining a virile farming population. In the same vein, the finding was consistent with [22], who posited that education is important for socio - awareness, perception, reception and the adoption of innovation that can bring about increase in Agricultural production. The finding was consistent with [38] who posits that educated individuals and households are better positioned to take advantage of new farming techniques and technologies that could lead to increased Agricultural output. [39] noted that education exposes an individual to the right methods of utilizing resources. This is more so for the beneficiaries whose high educational status enhances their ability to understand and derive necessary benefits accruing from the project. [18] Also asserts that higher levels of literacy increase the ability of farmers to cope with the complexities of new technologies and the intricacies of new product and factor markets. [40] Posit that participants of Agricultural projects benefit more when they have basic education such that they can appreciate the importance of these projects and the benefits they would derive from them. The bar chart representation of the percentage variations in the level of education of the sampled farmers in Fadama III Agricultural project in Bayelsa state is presented in figure 8 below.

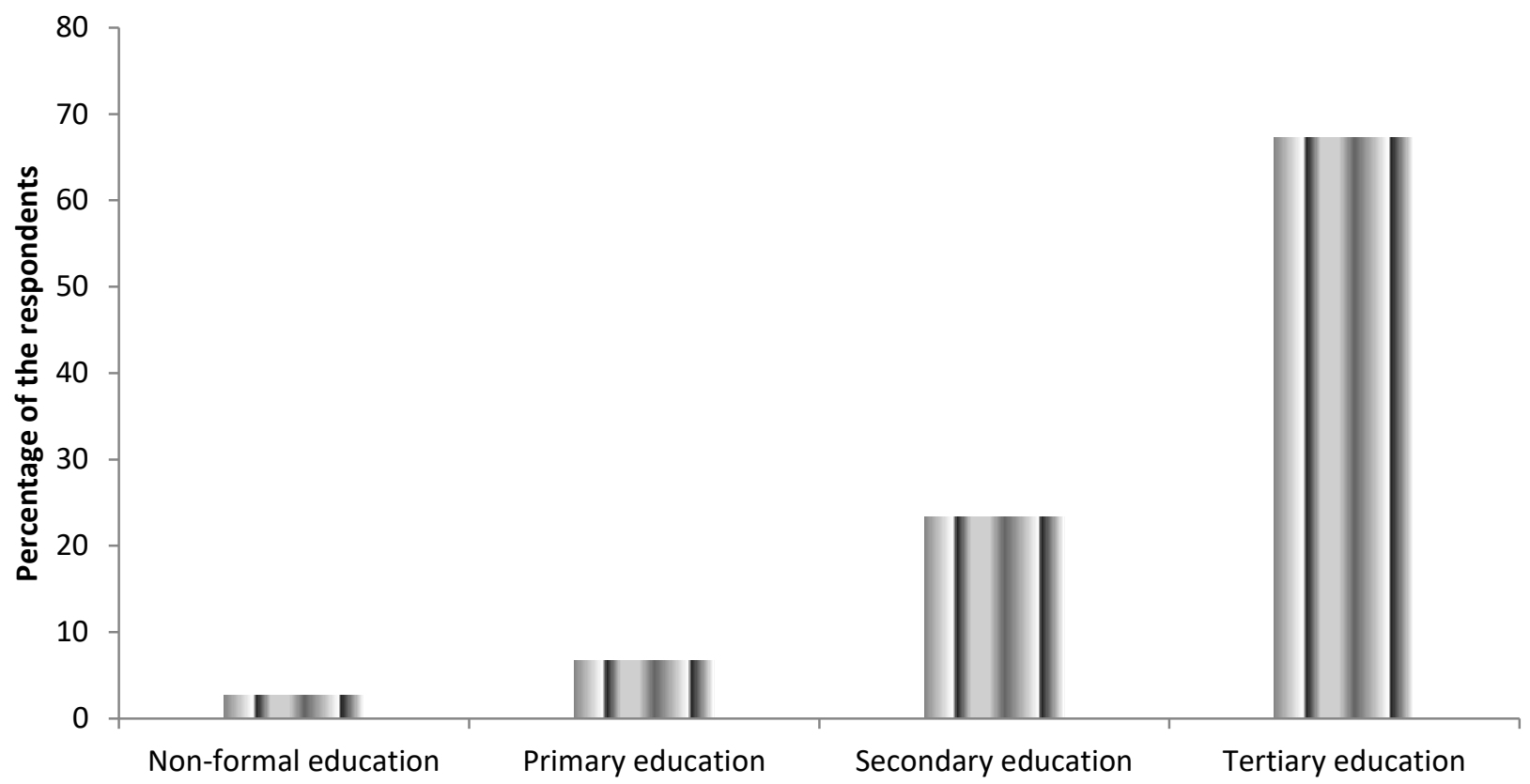

Fig. 8: percentage variations in the level of education of the sampled farmers in fadama iii agricultural projects in bayelsa state

\subsubsection{Farming experience}

The findings also showed that larger proportion $(55.3 \%$ of farmers in Fadama III Agricultural project in the study area had farming experience of at least 11 years. The mean years of farming experience of the farmers was twelve (12) years and one (1) months. This implies that the farmers in Fadama
III Agricultural project in Bayelsa state have been into farming for several years and may be considered quite experienced. As managers of the farm firm, farmers farming experience is an important factor for a successful farming business. Farming experience affects the income of farmers. This according to [25] may be due to the fact that farmers 
rely a lot on their farming experience for increased productivity. This study is consistent with [24] who agrees with this position, adding that the number of years a farmer has spent in the farming business may give an indication of practical knowledge he has acquired on how he could lovercome certain inherent farm production challenges. This study is consistent with [41] succinctly observed that farming experience enhances the participation and adoption of improved farming techniques, thereby increasing output.
This study is also consistent with [4] who asserted that experience in a business would enable a business operator to set realistic cost and time targets, allocate and utilized resources efficiently and identify production risks. The bar chart representation of the percentage variations in the farming experience of the sampled farmers in Fadama III Agricultural projects in Bayelsa state is presented in figure 9 below.

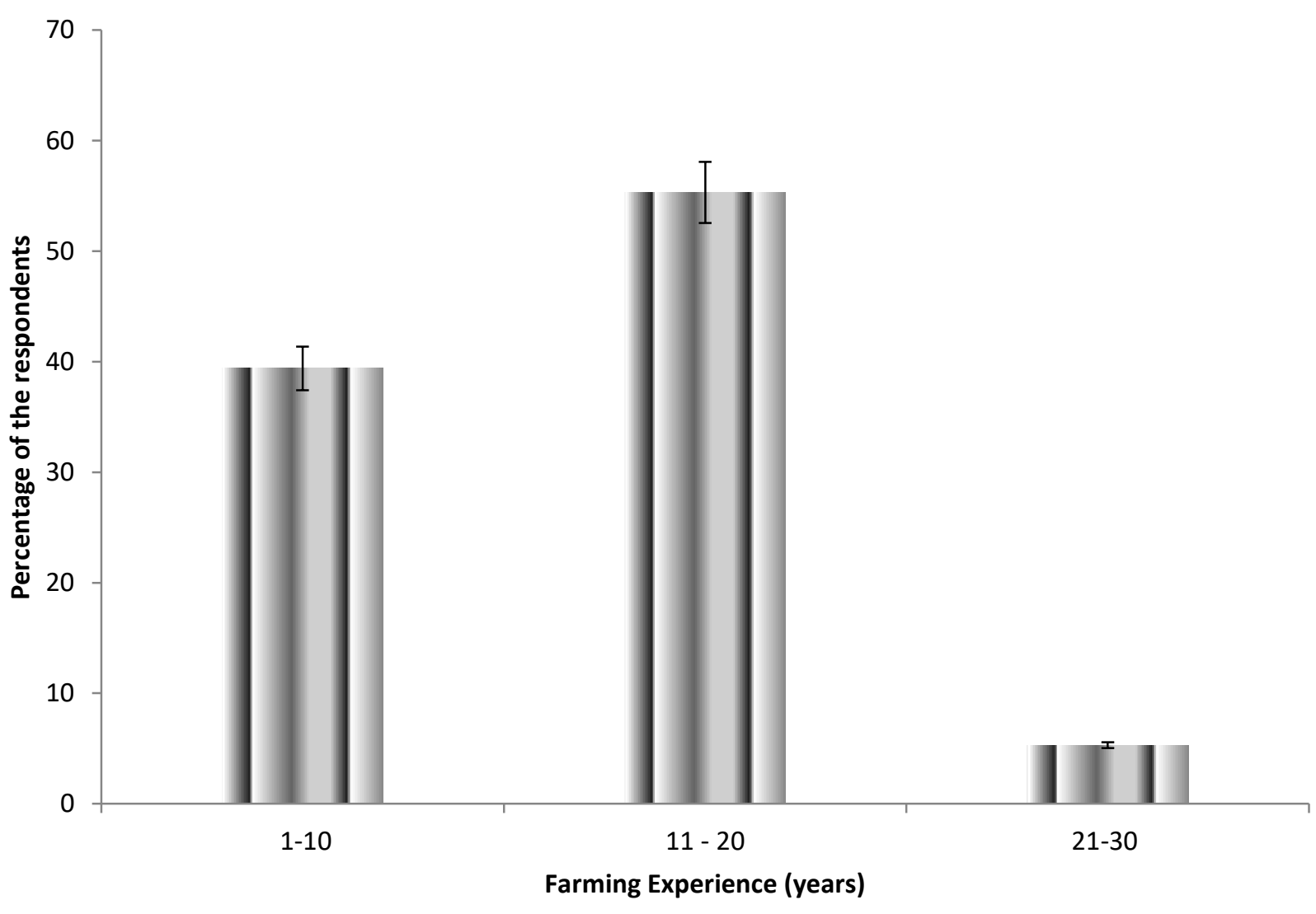

Fig. 9: percentage variations in the farming experience of the sampled farmers in fadama iii agricultural projects in bayelsa state.

\subsubsection{Years of active participation}

The findings showed that larger proportion (60.7 percent) of the sampled farmers in Fadama III Agricultural project in Bayelsa state have participated actively in Fadama III Agricultural project in Bayelsa state for at least three (3) years old while fewer proportion (39.3 percent) participated for at most two (2) years old. This implies that most of the participants in Fadama III Agricultural project in Bayelsa state have been in the project for long time and can to a high extent explain what is happening in the project in the state and how it has influenced their income status. The finding is consistent with [42] who posited that without participation; there are obviously no partnerships, no developments, and no program. Thus, no Agricultural project can successfully achieve its policy objective without active participation of the expected individual in such project. The pie chart representation of the percentage variations in the year of participation of the sampled farmers in Fadama III Agricultural project in Bayelsa state is presented in figure 10 below. 


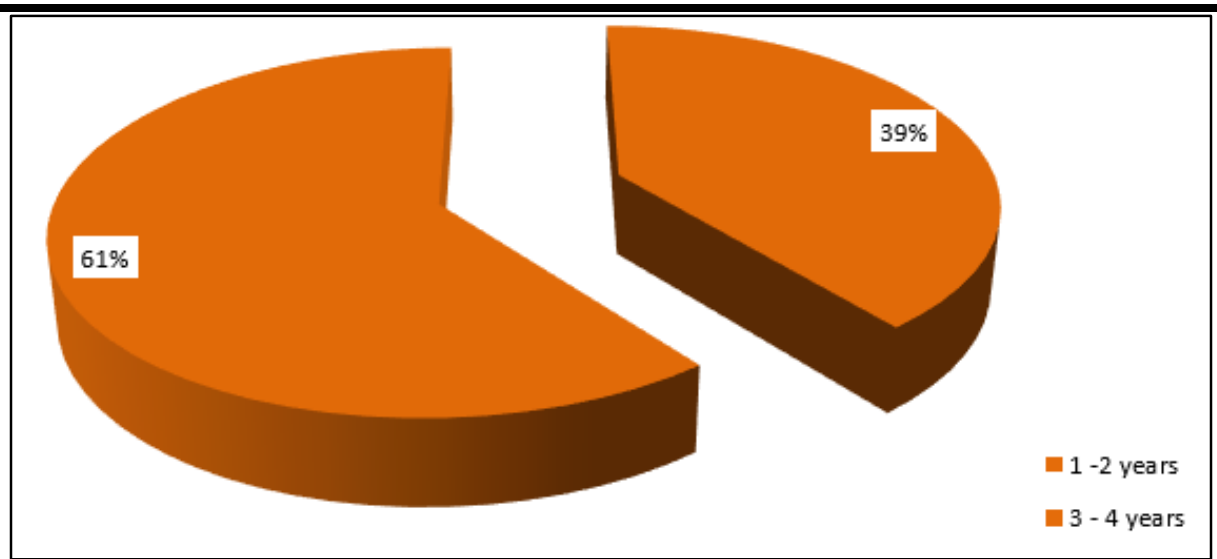

Fig. 10: percentage variations in the year of participation of the sampled farmers in fadama iii agricultural projects in bayelsa state

\subsubsection{Fadama extension agent visit}

The number of times extension agent visit participants of National Fadama III Agricultural project in Bayelsa State, larger proportion (38.7 percent) of the entire sampled farmers were visited by Extension Agent twice while fewer proportion (8.7 percent) was visited thrice. However, 53 participants which constitute 35.3 percent were not visited by Extension Agent(s) at all. This implies that extension visit to the farmers in the study area is very poor. Agricultural Extension services has been identified to be relevant in rapid increase in Agricultural production that aims to involve a shift from traditional resources based method to science based method which involves varieties of new cultural practices like use of fertilizer, organic manure, pesticides and capital investment inputs which farmers must learn how to use through the education role of extension workers [43]. Thus Agricultural Extension services aims at changing the rural people and train them to make independent decisions and make use of available local resource [44]. This suggested that the farmers in Fadama III Agricultural project were not receiving the needed encouragement from extension agents for their farming business and are not always communicated of new innovations and better farming system which may translate to higher output for the farmers. The bar chart representation of the percentage variations in the number of time extension agent visit participants of National Fadama III Agricultural project in Bayelsa State is presented in figure 11 below.

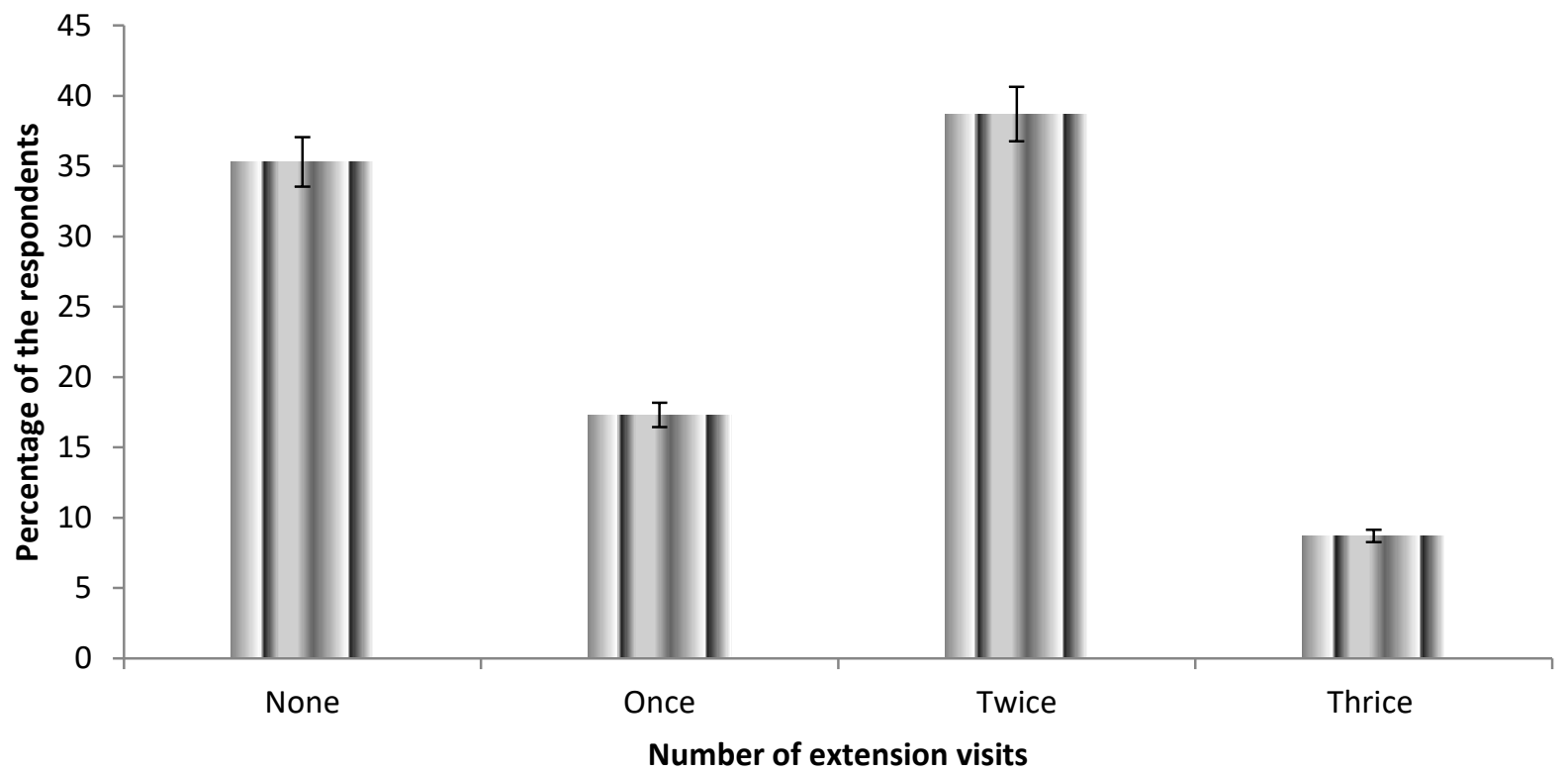

Fig. 11: number of time extension agent visit participants of national fadama iii agricultural project in bayelsa state. 
4.2.1 Factors that influence participants level of participation in fadama iii agricultural project in bayelsa state
The ordinary least square (OLS) regression result of the factors that influenced participant's level of participation in Fadama III agricultural project in the study area is presented in table 1 .

Table 1: Regression Result of the Factors that Influenced Participant's Level of Participation in Fadama III Agricultural Project in Bayelsa State

\begin{tabular}{lcccc}
\hline Variable & Linear & Exponential & Double-log & Semi-log \\
\hline Constant & 732.517 & 6.881 & 27.908 & 23509.001 \\
& $(8.184)^{* * *}$ & $(23.775)^{* * *}$ & $(6.297)^{* * *}$ & $(6.591)^{* * *}$ \\
Age of respondent & 6.788 & 0.019 & -1.753 & 2278.497 \\
& $(8.399)^{* * *}$ & $(7.409)^{* * *}$ & $(-4.497)^{* * *}$ & $(7.656)^{* * *}$ \\
Gender & 7.037 & 0.032 & -0.176 & 110.088 \\
& $(0.698)$ & $(0.981)$ & $(-0.670)$ & $(0.007)$ \\
Food security status & 1.197 & $-1.02 \mathrm{E}-05$ & -2.797 & -125.879 \\
& $(0.736)$ & $(-0.304)$ & $(-3.358)^{* * *}$ & $(-2.598)^{* *}$ \\
Household size & 2.434 & 0.007 & 1.227 & 341.971 \\
& $(1.138)$ & $(0.972)$ & $(2.358)^{* *}$ & $(0.821)$ \\
Income level & -6.287 & 0.001 & 1.249 & -242.530 \\
& $(-5.216)^{* * *}$ & $(2.337)^{* *}$ & $(3.713)^{* * *}$ & $(-0.427)$ \\
Poverty status & 6.497 & 1.024 & -2.255 & 614.087 \\
& $(3.319)^{* * *}$ & $(3.753)^{* * *}$ & $(-3.375)^{* * *}$ & $(2.410)^{* *}$ \\
Marital status & 4.001 & $-1.08 \mathrm{E}-06$ & -0.147 & 171.187 \\
& $(4.408)^{* * *}$ & $(0.874)$ & $(-1.313)$ & $(0.185)$ \\
Farm size & 1.712 & -0.028 & 0.068 & -213.337 \\
& $(1.121)$ & $(1.865)^{*}$ & $(0.918)$ & $(-1.931)^{*}$ \\
Leadership propensity & 65.938 & 0.353 & 1.887 & 109.409 \\
& $(3.656)^{* *}$ & $(4.062)^{* * *}$ & $(2.460)^{* *}$ & $(6.410)^{* * *}$ \\
Farming experience & 2.005 & $1.01 \mathrm{E}-05$ & 1.029 & -205.082 \\
& $(1.466)^{* * *}$ & $(2.409)^{* *}$ & $(3.071)^{* * * *}$ & $(-3.106)^{* * *}$ \\
Educational level & 6.788 & 0.019 & 1.413 & 2278.497 \\
& $(8.399)^{* * *}$ & $(7.409)^{* * *}$ & $(3.914)^{* * *}$ & $(7.656)^{* * *}$ \\
Distance to Fadama III & -4.250 & -0.068 & -1.793 & -166.542 \\
training centre & $(-3.042)^{* * *}$ & $(-2.729)^{* * *}$ & $(-2.393)^{* *}$ & $(-3.720)^{* * *}$ \\
Cooperative membership & 0.118 & 0.017 & 0.049 & 1320.227 \\
& $(1.520)$ & $(0.732)$ & $(1.065)$ & $(4.396)^{* * *}$ \\
$\mathrm{R}^{2}$ & 0.928 & 0.910 & 0.938 & 0.892 \\
Adj.R ${ }^{2}$ & 0.904 & 0.899 & 0.917 & 0.871 \\
F-statistics & $101.980^{* * * *}$ & $98.341^{* * * *}$ & $114.841^{* * * *}$ & $88.568 * * *$ \\
\hline
\end{tabular}

Source: Computed by the author from field survey data, 2016

*** Significant at 1\%; ** Significant at 5\% and * Significant at 10\%. Figures in parenthesis are t-values. L= means lead equation.

The double-log functional form was chosen as the lead equation based on the number of significant independent variable, magnitude of the coefficient of multiple determinations and conformity of the signs of the significant regression coefficient to a priori expectation. The overall goodness of fit of the equation as indicated by the coefficients of multiple determinations $\left(\mathrm{R}^{2}=0.938\right)$ indicates that the explanatory variables included in the model explained about $93.8 \%$ of the variation in the level of participation of the respondents in Fadama III agricultural project in Bayelsa state. The F- statistics of the lead model 
was significant at $1 \%$ and confirms the significance of the entire model.

Age of respondents, food security status, household size, and income level, and poverty status, leadership propensity, farming experience, educational level and distance to Fadama III training centre were the significant factors that influenced the level of participation of the respondents in Fadama III agricultural project in Bayelsa state.

The regression coefficient for age of respondents was negative and significant at $1 \%$ as it relates to the level of participation of the respondents in Fadama III agricultural project in Bayelsa state. This indicated an inverse relationship between level of participation and their age in years. This implies that the level of participation in Fadama III agricultural project in Bayelsa state decreases with increases in the age of the respondents. This suggests that younger farmers are more willing to participate in Fadama III agricultural project than their older counterparts. Therefore, level of participation in Fadama III agricultural project in Bayelsa state by the respondents is age dependent. This finding is in consonance with [45] who stated that younger farmers tend to be more willing to participate in agricultural development projects than their older counterparts. This result also agrees with the findings of [46]; [14]; [47] whose studies shows the dominance of middle aged farmers in agricultural activities and/or projects.

The regression coefficient for food security status of the respondents was negative and significant at $1 \%$ as it relates to the level of participation of the respondents in Fadama III agricultural project in Bayelsa state. This indicated an inverse relationship between level of participation and food security status of the respondents. This implies that the level of participation in Fadama III agricultural project in Bayelsa state increases with the respondents being food insecure (below the food security line). Food insecurity will cause most persons to participate more in any programme that will help to become food secured. The interest in getting over one's current food insecurity status will compel an individual to put in his/her best commitment to such programme so as to be well empowered to combat the menace of food insecurity. Therefore, level of participation by the respondents is dependent on their food security status. This assertion was supported by [38] who noted that the involvement of many farmers in Imo state in Fadama II Agricultural project was to improve upon their standard of living and food security through Agricultural commercialization; and by [48] whose report showed that for the sake of attaining food security, many farmers from developing economies participates in agricultural development projects and schemes.

The regression coefficient for household size was positive and significant at $5 \%$ as it relates to the level of participation of the respondents in Fadama III agricultural project in Bayelsa state. This indicated a direct relationship between level of participation and their household size. This implies that the level of participation in Fadama III agricultural project in Bayelsa state increases with increases in the household size of the respondents. This suggests that farmers with large household members participate in Fadama III agricultural project than those with small household members. Therefore, level of participation in Fadama III agricultural project in Bayelsa state by the respondents is dependent on their household size. This finding is in consonance with [38] and [49] whose studies shows that farmers with large household size participates more in agricultural projects that will enable them purvey their family needs.

The regression coefficient income level of the farmers was positive and significant at $1 \%$ as it relates to the level of participation of the respondents in Fadama III agricultural project in Bayelsa state. This indicated a direct relationship between level of participation by the respondents and their income level. This implies that the level of participation in Fadama III agricultural project in Bayelsa state increases with increases in the income level of the respondents. Level of income affects the standard of living of a farmer, as well as hinders the ability of a farmer to expand his/her farming business away from subsistence level. Farmers will be more willing to participate in Fadama project if the project promises to positively impact economically on their level of income [32]. This suggests that farmers whose income level improves due to participation in Fadama III agricultural projects will continue to participate in such agricultural projects. Therefore, level of participation in Fadama III agricultural project in Bayelsa state by the respondents is dependent on their level of income. This finding is in consonance with [38]; [49],[29] and [30] whose studies revealed that farmer's higher income level from agricultural projects motivates their continuous participation in agricultural projects.

The regression coefficient for poverty status of the respondents was negative and significant at $1 \%$ as it relates to the level of participation of the respondents in Fadama III agricultural project in Bayelsa state. This indicated an inverse relationship between level of participation and poverty status of the respondents. This implies that the level of participation in Fadama III agricultural project in Bayelsa 
state increases with the respondents being poor (where the mean household expenditure was used as poverty line). This suggests that farmers who are poor will strive to participate in Fadama III agricultural projects in lieu to better their poverty status. High level of poverty will influence a farming household to participate actively in National Fadama III Agricultural project as a means of poverty alleviation strategy. However, a farmer will not participate actively if there is no improvement in his/her poverty status after participating at certain level in the project. Level of participation in Fadama III agricultural project in Bayelsa state by the respondents is dependent on their poverty status. This finding is in line with [50], [38]; [51] and [52] showed that poor farmers mostly participated in Fadama projects in Nigeria.

The regression coefficient for leadership propensity of the Fadama III agricultural project agents was positive and significant at $5 \%$ as it relates to the level of participation of the respondents in Fadama III agricultural project in Bayelsa state. This indicated a direct relationship between level of participation by the respondents and leadership propensity of the Fadama III agricultural project agents. This implies that supportive leadership propensity of the Fadama III agricultural project agent's leads to more participation in Fadama III agricultural project in Bayelsa state by the respondents. Leadership propensity and time management in Fadama III Agricultural projects will positively influence the level of participation of farmers by making them to get committed more than usual in the projects and will also reflect in the rate of adoption of new farming technologies showcase by the project by the farmers. Therefore, level of participation of farmers in Fadama III agricultural project is dependent on the nature of the leadership propensity of the delivery agency.

The regression coefficient for farming experience was positive and significant at $1 \%$ as it relates to the level of participation of the respondents in Fadama III agricultural project in Bayelsa state. This implies that the level of participation in Fadama III agricultural project in Bayelsa state increases with increases in the farming experience of the farmers. This suggests that experienced farmers are more willing to participate in Fadama III agricultural project due to the benefits the derived from such agricultural projects than their inexperience counterparts. Therefore, level of participation in Fadama III agricultural project in Bayelsa state by the respondents is farming experience dependent. This finding is in consonance with [46]; [53]; [47]; and [52] whose studies shows the dominance of long experienced farmers in agricultural activities and/or projects than beginners in farming activities.

The regression coefficient for educational level of the farmers was positive and significant at $1 \%$ as it relates to the level of participation of the respondents in Fadama III agricultural project in Bayelsa state. This implies that the level of participation in Fadama III agricultural project in Bayelsa state increases with increases in the educational level of the farmers. This suggests that well educated farmers are more willing to participate in Fadama III agricultural project due to the benefits the derived from such agricultural projects than those with low level of education. Therefore, level of participation in Fadama III agricultural project in Bayelsa state by the respondents is dependent on the educational level of the farmers. This finding is in consonance with [53], [47], [52], and [51] whose studies shows the dominance of educated farmers in agricultural activities and/or projects in their various study areas.

The regression coefficient for distance to Fadama III agricultural project training centre was negative and significant at $5 \%$ as it relates to the level of participation of the respondents in Fadama III agricultural project in Bayelsa state. This implies that the level of participation in Fadama III agricultural project in Bayelsa state decreases with increases in the distance to Fadama III agricultural project training centre. This suggests that farmers are more willing to participate in Fadama III agricultural project with training centre closer to them than when the training centre is far and costs those more to transport themselves to the centre. Therefore, level of participation in Fadama III agricultural project in Bayelsa state by the respondents is dependent on the distance to Fadama III agricultural project training centre.

\section{CONCLUSION AND RECOMMENDATIONS}

Agricultural and rural development programs such as fadama III and others are fundamental to nation building and the agricultural sector is what can fast track the challenges faced by rural dwellers in terms of agricultural development in most of the developing countries, participants participated and are still willing to participate in such activities irrespective of their socioeconomic characteristics.

The study therefore recommend's that participants of younger age especially the youths should be encouraged in agricultural and rural development programs as age determines one's ability and willingness to participate in such programs effectively, also, programs of this nature 
should be of continues basis in other to overcome problems of food security in Nigeria and other developing countries.

Also, funds that are meant for agricultural projects should be properly disbursed to farmers on time to enable them participate actively as farmer's income levels motivate them to participate in agricultural and rural development programs. Scientist/extension training personnel's should frequently visit farmers to know their immediate challenges in time of program life cycle, this will always motivate participants to be more focused while participating and will make them adopt any new technology easily been made available for them.

\section{REFERENCES}

[1] Momoh O.M., Ehiobu N.O. and Nwosu C.C. 2007. Egg National Bureau of Statistics (NBS) 2006. Poverty Profile for Nigeria. National Bureau of Statistics, Abuja, Nigeria.

[2] ADF, 2003 Group Inc. v. United States of America, ICSID Case No ARB (AF)/00/1

[3] National Planning Commission (NPC) 2006. Community-Based Poverty Reduction Projects (CPRP) Operational Manual, Abuja, Nigeria, Pp 6. NSAP, Calabar 18th-21st March. pp. 149-151.

[4] Ibeagwa, O.B; Nnamerenwa, G.C. and Anorue. P.C. (2012). Analysis of Returns on Investment of cassava processing in Kwara State, Nigeria. Proceeding of the $26^{\text {th }}$ Annual conference of farm management Association of Nigeria, Michael Okpara University of Agriculture, Umudike, October $15^{\text {th }}-19^{\text {th }} 2012$.

[5] Nwosu, F.O., Oguoma, N.N.O. Ben-Chendo, N.G. and Henri-Ukoha, A. (2012), The Agricultural Credit Guarantee Scheme: Its Roles, Problems and Prospective in Nigerian's Quest for Agricultural Development. Researcher 2(2):1 -4.

[6] Afolabi J.A (2010). Analysis of loan repayment among small scale farmers in Oyo State Nigeria, Journal of social sciences, vol. 22(2): 115-119.

[7] Ukoha, H.A., Orebiyi, J.S. Obasi, P.C., Oguoma, N.N. Ohajianya D.O., Ibekwe, U.C and Ukoha I.I. (2011). Determinants of loan acquisition from the financial institution by small-scale farmers in Ohafia Agricultural zone of Abia State, South-East Nigeria, Journal of Development and Agricultural Economics, Vol. 3(2): 69-74.

[8] Mohammed, B. T. and Abdulquadri, A. F. (2012), Comparative analysis of gender involvement in agricultural production in Nigeria. Journal of Development and Agricultural Economics Vol. 4(8), pp. 240-244, 12 May, 2012 Available online at http://www.academicjournals.org/JDAE

[9] Lawanson TO (2010). Gender Differentials in Nigeria: Implications for Sustainable Urban development. Department of Urban and Regional Planning, University of Lagos Akoka Lagos

[10] Ayoola J. B., Odiaka EC (2004). Gender perspectives on Agricultural Development. Experience from Benue State of Nigeria. Proceeding of 38th Annual Conference of ASN, Nasara P.

[11] Nnadozie B, I Ibe (1996). Women in agriculture: Problems and prospects, In: Agricultural Transformation in Nigeria, Eds., A. C. Nwosu; C. U. Nwajuba and J. A. Mbanasor. Owerri, Nigeria: Novelty Industrial Enterprises.

[12] Rahman SA (2008). Women's involvement in agriculture in northern and southern Kaduna State. J. Gend. Stud., 17: 17-26.

[13] World Bank (2003). Nigeria: Women in agriculture, In: Sharing Experiences-Examples of Participating Approaches. The World Bank Group. The World Bank Participating Sourcebook, Washington, D.C. http:/www.worldbank.org/wbi/publications.htm

[14] Ironkwe A.G. and Olojede J.C. (2012). Socioeconomic factors influencing the output of cassava farmers in Abia State Nigeria proceedings of the $26^{\text {th }}$ Annual conf. FAMAN, Michael Okpara University of Agriculture Umudike October, $15^{\text {th }}-19^{\text {th }}, 2012: 55-58$.

[15]Ekong, E. E (2003). An Introduction to Rural Sociology (2nd edn). Dove Education Publishers, Uyo, Nigeria Pp 187-196.

[16]Ekong, E. E (2010). Rural Sociology, An Introduction and Analysis of Rural Nigeria (third edn). Dove Education Publishers Uyo pp 287-289.

[17] Olayode G.O, Aihonsu J.O.Y. Akerele, E.O. and Adeokun, O.A. (2005). Effect of Credit Use and Loan Default on Production of Arable Crops among small Scale Farmers in Ijebu Local Government Area of Ogun State, Nigeria; Journal of Agricultural Management and Rural Development vol.2:113-129.

[18] Onyebinama U.A. U. (2001)."An Analysis of the Prospect for Commercialization of Smallholder Agriculture in Imo State. Journal of Agricultural Technology 9(2): 50-58.

[19] Chikezie, N.P., Omokore D.F., Akpoko J.G. and Chikaire J. ( 2012). Factors Influencing Rural Youth Adoption of Cassava Recommended Production Practices in Onu-Imo Local Government Area of Imo 
State, Nigeria. Greener Journal of Agricultural Sciences 2(6), 259-268.

[20] Nnamerenwa,G.C. (2012). Analysis of intra sectoral credit allocation under the agricultural credit guarantee scheme funds in Nigeria (1978 -2009). M.Sc Thesis, Department of Agricultural Economics, Michael Okpara University of Agriculture Umudike, Abia state , Nigeria.

[21] Onyebinama, U.A.U. (2004). "Farm Business Management for Smallholder Farm Firms in Nigeria". Alphabet Nigeria Publishers, Owerri, Nigeria.

[22] Ojuekaiye, E. O. (2001). Economic Analysis of Cassava Production in Three Local Government Areas of Kogi

[23] Ashiegbu, C. O., (2015), Peertechz » Community Medicine Public Health 》 index (C) 2015 PeerTechz.com. All Rights Reserved, Published on 01 August, 2016 | Authors: Chikere Ifeanyi Casmir Ebirim*, Ugonma Winnie Dozie, Wanwuri Akor, Ijeoma Judith Dozie and Oluchi Agatha | Pages: 027-

[24] Nwaru, J.C. (2004). Rural Credit market and Resource use in Arable crop production in Imo State of Nigeria. Ph.D. Dissertation, Michael Okpara University of Agriculture, Umudike, Nigeria.

[25] Iheke R.O. (2010). "Migrant Remittances, Resource Use Efficiency and Welfare among Rural Smallholder Arable Crop Farm Households in South Eastern Nigeria”. PhD Dissertation; Department of Agricultural Economics, Michael Okpara University of Agriculture, Umudike, Nigeria.

[26] Unamma, R.P.A; Onwudike, O.C.; Uwaegbute, A.C.; Edeoga, H.O.; and Nwosu A.C. (Ed.s) (2004). Linkage strategy for sustainable Agriculture in NigeriaResearch-Extension-Farmer-Input-Linkage System (REFILS), Michael Okpara University of Agriculture, Umudike.

[27]Ike, P.C. and U.N. Uzokwe, (2011). Estimation of Poverty among Rural Farming Households in Delta State, Nigeria. International Journal. of Agriculture Food Science and Technology, 2(1): 11-21.

[28]Davis, C.G., M. Moussie, J.S. Dinning and G.J.Christakis (1982). "Socioeconomic Determinants of Urban Households Food Expenditure Patterns: An Empirical Analysis". Department of Food and Resource Economics University of Florida, U.S.A.

[29] Ingawa, S.A.(2009), Implementation Completion Report (ICR)of the World Bank Assisted $2^{\text {nd }}$ National Fadama Development Project Food Reserve Agency
(NFRA) Federal Ministry of Agriculture and Water Resources, Abuja.

[30] Nkonya E., T. Mogues, J. Pender, M.K. Yahaya, G. Adebowale, T. Arokoyo, E. Kato (2008). "From the Growing Up", Impacts of a Pro- Poor CommunityDriven Development Project in Nigeria. IFPRI Discussion Paper, 00756, March, 2008.

[31] Aigbokhan, B.E. (2000)." Poverty and Growth and Inequality in Nigeria: A case study". African Economic Research Consortium (AERC) Research paper 102, Nairobi, November, 2000

[32] Onyemauwa, C.S. (2005). "Comparative analysis Fadama and Non-Fadama Project Farmers in Imo State". An MSc thesis at Federal University of Technology Owerri, Nigeria.

[33] Adegbite, D. A., Oloruntoba, A. O, Adubi, K. O, Oyekunle, O. and Sobanke, S B., (2008): Impact of National Fadama Development Project II on Small Scale Farmers in Ogun State: Implication for Agricultural Financing in Nigeria, Journal of Sustainable Development in Africa, 10 (3): 103- 126. Clarion University, Pennsylvania.

[34] Bajoga, Y. U. and Adebayo, A.A. (2006): The Impact of Fadama Development Project on the Living Standard of Dry Season Farmers of Gombe State, Journal of Environment, 1(1): 7-13.

[35] Hamadina, M. K. , and Hamadina, E. I. (2015). Smallholder Farmers and Sustainability Issues: the Case of Fadama III Sub-Projects in Bayelsa State of Nigeria. Journal of Multidisciplinary Engineering Science and Technology (JMEST) ISSN: 3159-0040 Vol. 2 Issue 4, April - 2015

[36] Ogunbameru, B. O. (2001). Practical Agricultural Communication, Ibadan, Daily Graphic Publications. Ibadan. pp

[37] Ani, A.O. (2006), Women in Agriculture and Rural Development, Prisquilla Publishers, Nigeria. Pp. 84

[38] Ibeagwa, O.B. (2011). Effect of SNFDP on the income and welfare of farm households in Imo State. M.Sc Thesis, Department of Agricultural Economics, Michael Okpara University of Agriculture Umudike, Abia state, Nigeria.

[39] Ogbe, S.E (2009). “ Determinants of Credit Demand and Microfinance Outreach to Farmers in Abia State: a case study of National Special Programme on Food Security". MSc. Thesis, Michael Okpara University of Agriculture, Umudike.

[40] Amamgbo, L.E.F. ,A.O. Akinpelu, M.C. Okwusi and S.E. Tolubanwo (2006). "Analysis of factors 
influencing the utilization of Sweet Potato Flour for

Confection in the South-east Agro-ecological Zone". Proceedings of the $40^{\text {th }}$ Conference of the Agricultural Society of Nigeria. Pp. $268-269$.

[41] Nwaobiala, C .U. and Onumadu, F. N. 2010. Youths Participation in Cassava Production Through Rural Extension Project of Federal College of Agriculture Ishiagu IVO LGA of Ebonyi State, Nigeria. Proceedings of the 44th Annual Conference of Agricultural Society of Nigeria (ASN) Held at LAUTECH Ogbomoso Osun State, Nigeria 1822October Pp 50-52.

[42] Aref, F., Marof R. and Sarjit S. G. (2010) Community capacity building: A review of its implications in tourism development. J. Amer. Sci. 6(1), 172-180.

[43] Williams, S.K.T (1999) Sources of Information on improved farming practices in some selected areas of western Nigeria. Bulleting of rural economics and Sociology, p65.

[44] Maunder B.C. (2002) Agricultural extension a reference manual FAO publication Rome.

[45] Gareux L M (2003). Cotton Producers in Africa vis US and EU Subsidies. Prelude to the Cancun Negotiations. European Parliament: Brussels, pp. 4-10.

[46] Kankwenda, M., L. Gregoire, H. Legros and H. Ouedraogo, 2000. Poverty eradication; where stands Africa? London: UNDP. Economical Limited.

[47] Danjuma I. A., Oruonye, E.D., Ahmed, Y.M. (2016). The Socio-Economic Impact of Fadama III Project in Taraba State: A Case Study of Jalingo Local Government Area. International Journal of Environmental \& Agriculture Research (IJOEAR), 2(2), $35-41$.

[48]Food and Agriculture Organisation, (1996). Youth works. An Information note on Rural Youth and Young

[49] Inyang, N.U. (2014). Evaluation of effect of integrated farmers scheme on youth empowerment in Akwa Ibom State, Nigeria. Msc Thesis. Department of Rural Sociology and Extension, Michael Okpara University of Agriculture Umudike Abia state.

[50] Ogbonna, M. O and Nwaobiala, C. U. (2015). Evaluation of Participation and Poverty Levels of National FADAMA III Development Project Rural Farm Women in Gombe State, Nigeria. Discourse Journal of Agriculture and Food Sciences. 3(6), 83 90.

[51] Ezeh, C. I. (2009) The Impact of the National Fadama II Development Project in Alleviating Rural Poverty and Improving Agricultural Production in Imo State, Nigeria, Agro-Science: Journal of Tropical Agriculture, Food, Environment and Extension, 8 (3): $139-144$

[52]Ezeh, C. I.. (2012). Midline Impact Study of the National Fadama III Development Project in Abia State, Nigeria. Paper Presented to Abia State Fadama III Coordinating Office, Abia State Office, Umuahia.

[53] Ironkwe, A.G. (2011). "Gender and Yam Minisett Technology Development, Transfer and Utilization in Southeast Agro-ecological Zone of Nigeria". Ph.D. Dissertation, Department of Rural Sociology and Extension, Michael Okpara University of Agriculture, Umudike, Nigeria. Pp.50-67. 